\title{
ANALISIS TREND OMZET PEJUALAN SEPATU DAN SANDAL DI CV. PRIBADI TIGA KOTA MOJOKERTO TAHUN 2015-2017
}

\author{
Farida Florensia $^{1}$, Joko Widodo ${ }^{1}$, Titin Kartini ${ }^{1}$ \\ ${ }^{1}$ Program Studi Pendidikan Ekonomi, Fakultas Keguruan dan Ilmu Pendidikan, Universitas Jember \\ e-mail: faridaflorensia53@gmail.com
}

\begin{abstract}
Abstrak
Penelitian ini dilakukan untuk mendeskripsikan trend omzet penjualan sepatu dan sandal di CV. Pribadi Tiga Kota Mojokerto selama tahun 2015-2017. Penelitian ini merupakan jenis penelitian deskriptif dengan pendekatan kuantitatif. Penentuan lokasi penelitian menggunakan metode purposive area yaitu di CV. Pribadi Tiga Kota Mojokerto. Subjek penelitian adalah pemilik CV. Pribadi Tiga. Metode pengumpulan data menggunakan metode dokumen, wawancara, dan observasi. Analisis data yang digunakan yaitu analisis trend dengan menggunakan metode Least Square. Hasil penelitian menunjukkan bahwa trend omzet penjualan di CV. Pribadi Tiga tahun 2015-2017 mengalami peningkatan. Ketertarikan konsumen melakukan pembelian di CV. Pribadi Tiga dikarenakan perusahaan memberikan pelayanan yang berbeda yaitu konsumen dapat melakukan pemesanan sepatu, sandal maupun tas sesuai dengan keinginan dan kebutuhan konsumen. Selain itu CV. Pribadi Tiga juga memberikan garansi pada produknya dan juga menerima servis sepatu, sandal maupun tas. Sehingga hal tersebut sangat bermanfaat untuk perkembangan perusahaan terutama berkaitan dengan pencapaian omzet penjualan.
\end{abstract}

Kata Kunci: Trend, Omzet Penjualan, Pelayanan

\section{PENDAHULUAN}

Industri sepatu merupakan salah satu industri yang pesat perkembangannya di Indonesia termasuk di Kota Mojokerto. Hal ini disebabkan oleh kebutuhan masyarakat terhadap sepatu berpengaruh pada kegiatan masyarakat sehari-hari. Tingginya kebutuhan sepatu menyebabkan banyak industri mengalami kemajuan yang cukup besar, dikarenakan munculnya inovasi-inovasi sepatu berdasarkan dengan kebutuhan dan permintaan konsumen.

Tujuan suatu industri didirikan adalah untuk meningkatkan omzet penjualan dan juga menghasilkan laba yang optimal. Adanya tujuan tersebut, produsen suatu industri harus menentukan cara yang efektif untuk dapat menarik minat konsumen agar membeli produk yang ditawarkan. Semakin tinggi daya beli masyarakat, maka permintaan akan suatu barang dan jasa akan meningkat dari sisi kuantitas maupun kualitasnya. Hal ini sangat menentukan besarnya jumlah barang yang mampu terjual sehingga omzet penjualan akan semakin meningkat.

Omzet penjualan merupakan tolak ukur keberhasilan jumlah penjualan suatu industri dan merupakan total keseluruhan jumlah pendapatan yang diperoleh oleh suatu industri dari hasil penjualan dalam kurun waktu tertentu biasanya dihitung dalam satu tahun. Menurut Direktorat Jenderal Pajak (2017) omzet penjualan adalah penjualan kotor tiap bulan semua gerai, counter, outlet, baik Pusat maupun Cabang, yang dilakukan secara langsung dan/atau melalui media online. Perkembangan suatu perusahaan dapat dilihat dari kenaikan atau penurunan jumlah penjualan yang dihasilkan oleh suatu perusahaan.

CV. Pribadi Tiga merupakan salah satu industri sepatu dan sandal berbahan kulit yang berdiri di Kota Mojokerto dan memproduksi beragam sepatu, sepatu sandal, sandal, dan tas. CV. Pribadi Tiga memiliki ruang galeri atau toko untuk memasarkan produknya di Jl. KH. Usman No. 22 Surodinawan Kota Mojokerto. Hasil produksi tersebut dipasarkan di beberapa kota di luar Mojokerto, bahkan di luar pulau Jawa. Hal ini menyebabkan pencapaian omzet penjualan CV. Pribadi Tiga dapat meningkat dari tahun ke tahun.

Menjelang tahun ajaran baru, CV. Pribadi Tiga memproduksi sepatu dalam jumlah yang lebih banyak dikarenakan permintaan sepatu untuk para peserta didik setiap tahunnya meningkat untuk memasuki ajaran baru di sekolah. Hal ini merupakan kebijakan yang diterapkan oleh pemerintah Kota Mojokerto untuk menggunakan produk yang menjadi unggulan daerah tersebut. Semakin banyaknya permintaan akan sepatu dan sandal maka CV. Pribadi Tiga mampu meningkatkan jumlah produksi yang dapat berpengaruh pada peningkatan omzet 
penjualan yang diperoleh.

Suatu industri harus dapat mengikuti perkembangan yang terjadi saat ini, agar industri tersebut dapat tetap bertahan dalam pasar. Salah satu upaya yang dapat dilakukan yaitu dengan melakukan berbagai kegiatan dalam bidang pemasaran. Menurut Kartajaya, H (2010:5) Pemasaran merupakan jawaban dalam menghadapi persaingan bisnis di masa depan. Apabila terus melakukan evolusi pemasaran, sebuah institusi dapat terus mempertahankan relevansinya di tengah lanskap bisnis yang terus berubah sehingga diperlukan manajemen pemasaran yang baik pula.

Kegiatan pemasaran yang diterapkan oleh pemilik CV. Pribadi Tiga adalah memasarkan hasil produksinya melalui ruang galeri atau toko, namun juga memasarkan melalui situs jual beli online yaitu di Qlapa.com. Selain memasarkan produknya, CV. Pribadi Tiga juga memberikan beberapa pelayanan kepada konsumen berupa pemberian garansi pada pembelian produk; melayani perbaikan dari pembelian sepatu, sepatu sandal, dan tas; dan juga melayani pemesanan sepatu dan sepatu sandal sesuai dengan keinginan konsumen. Berdasarkan berbagai cara yang dilakukan tersebut diharapkan dapat meningkatkan volume produksi sehingga dapat meningkatkan omzet penjualan juga.

Berdasarkan pemaparan di atas, maka penelitian ini bertujuan untuk mengetahui analisis trend omzet penjualan sepatu dan sandal di CV. Pribadi Tiga Kota Mojokerto tahun 2015-2017.

\section{METODE PENELITIAN}

Penelitian ini merupakan penelitian deskriptif dengan pendekatan kuantitatif. Lokasi penelitian ditentukan dengan menggunakan metode purposive area, dimana lokasi ditentukan langsung oleh peneliti yaitu di CV. Pribadi Tiga Jalan KH. Usman No. 22, Surodinawan, Kecamatan Prajurit Kulon Kota Mojokerto. Subjek penelitian yaitu pemilik CV. Pribadi Tiga. Metode yang digunakan untuk pengumpulan data terdiri dari: metode dokumen dilakukan untuk mendapatkan data primer atau data utama, yaitu berupa data omzet penjualan selama tiga tahun tahun 2015-2017. Metode wawancara dilakukan untuk mendapatkan data sekunder atau data pendukung yaitu berupa kegiatan pemasaran dan penjualan yang dilakukan oleh CV. Pribadi Tiga dan juga profil, alamat, sejarah dari CV. Pribadi Tiga.

Analisis data yang digunakan adalah analisis data berkala yang menerangkan dan mengukur berbagai perubahan atau perkembangan data selama satu periode (Hasan, 2009:184). Metode analisis data menggunakan analisis trend dengan metode kuadrat terkecil (Least Square). Rumus yang digunakan dalam metode Least Square :

Keterangan :

$$
\hat{Y}=\alpha+b X
$$

$\hat{\mathrm{Y}}=$ data berkala atau nilai trend untuk periode tertentu

$X=$ periode waktu (bulan)

$\alpha=$ konstanta, nilai $\hat{Y}$ jika $\mathrm{X}=0$

$b=$ koefisien $\mathrm{X}$, kemiringan garis trend (slope)

\section{HASIL DAN PEMBAHASAN}

\section{Hasil Penelitian}

Setelah mendapatkan data utama, maka dilakukan perhitungan dengan menggunakan analisis trend, yang bertujuan untuk melakukan suatu estimasi atau peramalan pada masa yang akan datang (Atmaja, 2009:75). Berikut ini adalah hasil perhitungan omzet penjualan selama tahun 2015-2017 dengan analisis trend menggunakan metode Least Square :

\section{a. Trend Omzet Penjualan Sepatu dan Sandal Tahun 2015}

Tabel 1. Perhitungan Trend Omzet Penjualan Sepatu dan Sandal Tahun 2015

\begin{tabular}{lccccc}
\hline \multicolumn{1}{c}{$\mathbf{n}($ Bulan) } & Omzet Penjualan $(\mathbf{Y})$ & $\mathbf{X}$ & $\mathbf{X Y}$ & $X^{2}$ & Trend \\
\hline Januari & $\operatorname{Rp~} 120.246 .000$ & -11 & $(1.322 .706 .000)$ & 121 & $104.935 .195,5$ \\
Februari & $\operatorname{Rp~} 59.556 .000$ & -9 & $(536.004 .000)$ & 81 & $114.828 .010,7$ \\
\hline
\end{tabular}




\begin{tabular}{|c|c|c|c|c|c|}
\hline Maret & Rp 115.989.800 & -7 & $(811.928 .600)$ & 49 & $124.720 .825,9$ \\
\hline April & Rp 130.649.000 & -5 & $(653.245 .000)$ & 25 & $134.613 .641,1$ \\
\hline Mei & Rp 113.946.000 & -3 & $(341.838 .000)$ & 9 & $144.506 .456,4$ \\
\hline Juni & Rp 168.780 .000 & -1 & $(168.780 .000)$ & 1 & $154.399 .271,6$ \\
\hline Juli & Rp 165.500.000 & +1 & 165.500 .000 & 1 & $164.292 .086,8$ \\
\hline Agustus & Rp 294.017.500 & +3 & 882.052 .500 & 9 & 174.184 .902 \\
\hline September & Rp 197.517.600 & +5 & 987.588 .000 & 25 & $184.077 .717,2$ \\
\hline Oktober & $\operatorname{Rp} 272.067 .500$ & +7 & 1.904 .472 .500 & 49 & $193.970 .532,4$ \\
\hline November & Rp 144.216.250 & +9 & 1.297 .946 .250 & 81 & $203.863 .347,6$ \\
\hline Desember & Rp 129.662.500 & +11 & 1.426 .287 .500 & 121 & $213.756 .162,8$ \\
\hline JUMLAH ( $(\Sigma)$ & Rp 1.912.148.150 & $\mathbf{0}$ & 2.829 .345 .150 & 572 & 1.912 .148 .150 \\
\hline
\end{tabular}

Berdasarkan tabel perhitungan omzet penjualan sepatu dan sandal menurut garis trend di atas dapat diketahui bahwa trend omzet penjualan sepatu dan sandal tahun 2015 mulai bulan Januari sampai Desember mengalami kenaikan. Jumlah omzet penjualan tertinggi terdapat pada bulan Agustus, sedangkan jumlah omzet penjualan terendah terdapat pada bulan Februari.

\section{b. Trend Omzet Penjualan Sepatu dan Sandal Tahun 2016}

Tabel 2. Perhitungan Trend Omzet Penjualan Sepatu dan Sandal Tahun 2016

\begin{tabular}{lccclc}
\hline \multicolumn{1}{c}{ n (Bulan) } & Omzet Penjualan $(\mathbf{Y})$ & $\mathbf{X}$ & $\mathbf{X Y}$ & $\boldsymbol{X}^{\mathbf{2}}$ & Trend \\
\hline Januari & Rp 123.665 .000 & -11 & $(1.360 .315 .000)$ & 121 & $127.389 .078,2$ \\
Februari & Rp 118.558 .000 & -9 & $(1.067 .022 .000)$ & 81 & $127.879 .135,2$ \\
Maret & Rp 137.459 .000 & -7 & $(962.213 .000)$ & 49 & $128.369 .192,2$ \\
April & Rp 120.380 .000 & -5 & $(601.900 .000)$ & 25 & $128.859 .249,2$ \\
Mei & Rp 176.895 .000 & -3 & $(530.685 .000)$ & 9 & $129.349 .306,2$ \\
Juni & Rp 96.403 .000 & -1 & $(96.403 .200)$ & 1 & $129.839 .363,2$ \\
Juli & Rp 117.380 .000 & +1 & 117.380 .000 & 1 & $130.329 .420,2$ \\
Agustus & Rp 169.370 .000 & +3 & 508.110 .000 & 9 & $130.819 .477,2$ \\
September & Rp 94.821 .000 & +5 & 474.105 .000 & 25 & $131.309 .534,2$ \\
Oktober & Rp 139.662 .000 & +7 & 977.634 .000 & 49 & $131.799 .591,2$ \\
November & Rp 124.574 .500 & +9 & 1.121 .170 .000 & 81 & $132.289 .648,2$ \\
Desember & Rp 141.845 .000 & +11 & 1.560 .295 .000 & 121 & $132.779 .705,2$ \\
\hline JUMLAH $(\boldsymbol{\Sigma})$ & Rp $\mathbf{1 . 5 6 1 . 0 1 2 . 7 0 0}$ & $\mathbf{0}$ & $\mathbf{1 4 0 . 1 5 6 . 3 0 0}$ & $\mathbf{5 7 2}$ & $\mathbf{1 . 5 6 1 . 0 1 2 . 7 0 0 , 2}$ \\
\hline
\end{tabular}

Berdasarkan tabel perhitungan omzet penjualan sepatu dan sandal menurut garis trend di atas dapat diketahui bahwa trend omzet penjualan sepatu dan sandal tahun 2016 mulai bulan Januari sampai Desember mengalami kenaikan. Jumlah omzet penjualan tertinggi terdapat pada bulan Mei, sedangkan jumlah omzet penjualan terendah terdapat pada bulan September.

c. Trend Omzet Penjualan Sepatu dan Sandal Tahun 2017

Tabel 3. Perhitungan Trend Omzet Penjualan Sepatu dan Sandal Tahun 2017

\begin{tabular}{lcccccc}
\hline \multicolumn{1}{c}{ n (Bulan) } & Omzet Penjualan $(\mathbf{Y})$ & $\mathbf{X}$ & $\mathbf{X Y}$ & $\boldsymbol{X}^{2}$ & Trend \\
\hline Januari & Rp 170.070 .000 & -11 & $(1.870 .770 .000)$ & 121 & $163.400 .957,9$ \\
Februari & Rp 116.065 .000 & -9 & $(1.044 .585 .000)$ & 81 & $162.790 .637,9$ \\
Maret & Rp 120.944 .000 & -7 & $(846.608 .000)$ & 49 & $162.180 .317,9$ \\
April & Rp 159.834 .750 & -5 & $(799.173 .750)$ & 25 & $161.569 .997,9$ \\
Mei & Rp 182.035 .875 & -3 & $(546.107 .625)$ & 9 & $160.959 .677,9$ \\
Juni & Rp 225.510 .000 & -1 & $(225.510 .000)$ & 1 & $160.349 .357,9$ \\
Juli & Rp 207.608 .800 & +1 & 207.608 .800 & 1 & $159.739 .037,9$ \\
Agustus & Rp 209.557 .500 & +3 & 628.672 .500 & 9 & $159.128 .717,9$ \\
\hline
\end{tabular}




\begin{tabular}{lcccccc}
\hline September & Rp 131.488 .000 & +5 & 657.440 .000 & 25 & $158.518 .397,9$ \\
Oktober & Rp 125.438 .500 & +7 & 898.069 .500 & 49 & $157.908 .077,9$ \\
November & Rp 102.672 .700 & +9 & 924.054 .300 & 81 & $157.297 .757,9$ \\
Desember & Rp 169.305 .250 & +11 & 1.862 .357 .750 & 121 & $156.687 .437,9$ \\
\hline JUMLAH $(\boldsymbol{\Sigma})$ & Rp $\mathbf{1 . 9 2 0 . 5 3 0 . 3 7 5}$ & $\mathbf{0}$ & $\mathbf{( 1 7 4 . 5 5 1 . 5 2 5 )}$ & $\mathbf{5 7 2}$ & $\mathbf{1 . 9 2 0 . 5 3 0 . 3 7 3 , 8}$ \\
\hline
\end{tabular}

Berdasarkan tabel perhitungan omzet penjualan sepatu dan sandal menurut garis trend di atas dapat diketahui bahwa trend omzet penjualan sepatu dan sandal tahun 2016 mulai bulan Januari sampai Desember mengalami penurunan. Jumlah omzet penjualan tertinggi terdapat pada bulan Juni, sedangkan jumlah omzet penjualan terendah terdapat pada bulan November.

\section{d. Trend Omzet Penjualan Sepatu dan Sandal Tahun 2015-2017}

Pada pembahasan sebelumnya, trend jumlah omzet penjualan hanya dihitung per tahun, maka pada pembahasan selanjutnya trend jumlah omzet penjualan dihitung selama 3 tahun atau 36 bulan. Berikut ini adalah perhitungan analisis trend menggunakan metode Least Square:

Tabel 4. Perhitungan Trend Omzet Penjualan Sepatu dan Sandal Tahun 2015-2017

\begin{tabular}{|c|c|c|c|c|c|}
\hline Bulan & Omzet Penjualan & $\mathrm{X}$ & $\mathrm{XY}$ & $X^{2}$ & Trend \\
\hline Januari, 2015 & Rp 120.246.000 & -35 & $(4.208 .610 .000)$ & 1225 & $143.076 .726,2$ \\
\hline Februari, 2015 & $\mathrm{Rp} \quad 59.556 .000$ & -33 & $(1.965 .348 .000)$ & 1089 & $143.462 .327,6$ \\
\hline Maret, 2015 & Rp 115.989.800 & -31 & $(3.595 .683 .800)$ & 961 & 143.847 .929 \\
\hline April, 2015 & Rp 130.649.000 & -29 & $(3.788 .821 .000)$ & 841 & $144.233 .530,4$ \\
\hline Mei, 2015 & Rp 113.946.000 & -27 & $(3.076 .542 .000)$ & 729 & $144.619 .131,8$ \\
\hline Juni, 2015 & Rp 168.780.000 & -25 & $(4.219 .500 .000)$ & 625 & $145.004 .733,2$ \\
\hline Juli, 2015 & $\mathrm{Rp} 165.500 .000$ & -23 & $(3.806 .500 .000)$ & 529 & $145.390 .334,6$ \\
\hline Agustus, 2015 & Rp 294.017.500 & -21 & $(6.174 .367 .500)$ & 441 & 145.775 .936 \\
\hline September, 2015 & Rp 197.517.600 & -19 & $(3.752 .834 .400)$ & 361 & $146.161 .537,4$ \\
\hline Oktober, 2015 & Rp 272.067.500 & -17 & $(4.625 .147 .500)$ & 289 & $146.547 .138,8$ \\
\hline November, 2015 & $\mathrm{Rp} 144.216 .250$ & -15 & $(2.163 .243 .750)$ & 225 & $146.932 .740,2$ \\
\hline Desember, 2015 & Rp 129.662.500 & -13 & $(1.685 .612 .500)$ & 169 & $147.318 .341,6$ \\
\hline Januari, 2016 & Rp 123.665.000 & -11 & $(1.360 .315 .000)$ & 121 & 147.703 .943 \\
\hline Februari, 2016 & Rp 118.558.000 & -9 & $(1.067 .022 .000)$ & 81 & $148.089 .544,4$ \\
\hline Maret, 2016 & $\mathrm{Rp} 137.459 .000$ & -7 & $(962.213 .000)$ & 49 & $148.475 .145,8$ \\
\hline April, 2016 & $\mathrm{Rp} 120.380 .000$ & -5 & $(601.900 .000)$ & 25 & $148.860 .747,2$ \\
\hline Mei, 2016 & Rp 176.895.000 & -3 & $(530.685 .000)$ & 9 & $149.246 .348,6$ \\
\hline Juni, 2016 & $\mathrm{Rp} \quad 96.403 .200$ & -1 & $(96.403 .000)$ & 1 & 149.631 .950 \\
\hline Juli, 2016 & Rp 117.380.000 & 1 & 117.380 .000 & 1 & $150.017 .551,4$ \\
\hline Agustus, 2016 & Rp 169.370.000 & 3 & 508.110 .000 & 9 & $150.403 .152,8$ \\
\hline September, 2016 & $\mathrm{Rp} \quad 94.821 .000$ & 5 & 474.105 .000 & 25 & $150.788 .754,2$ \\
\hline Oktober, 2016 & Rp 139.662.000 & 7 & 977.634 .000 & 49 & $151.174 .355,6$ \\
\hline November, 2016 & Rp 124.574.500 & 9 & 1.121 .170 .500 & 81 & 151.559 .957 \\
\hline
\end{tabular}




\begin{tabular}{llllll}
\hline & & & & & \\
Desember, 2016 & Rp 141.845.000 & 11 & 1.560 .295 .000 & 121 & $151.945 .558,4$ \\
Januari, 2017 & Rp 170.070.000 & 13 & 2.210 .910 .000 & 169 & $152.331 .159,8$ \\
Februari, 2017 & Rp 116.065.000 & 15 & 1.740 .975 .000 & 225 & $152.716 .761,2$ \\
Maret, 2017 & Rp 120.944.000 & 17 & 2.056 .048 .000 & 289 & $153.102 .362,6$ \\
April, 2017 & Rp 159.834.750 & 19 & 3.036 .860 .250 & 361 & 153.487 .964 \\
Mei, 2017 & Rp 182.035.875 & 21 & 3.822 .753 .375 & 441 & $153.873 .565,4$ \\
\hline Juni, 2017 & Rp 225.510.000 & 23 & 5.186 .730 .000 & 529 & $154.259 .166,8$ \\
Juli, 2017 & Rp 207.608.800 & 25 & 5.190 .220 .000 & 625 & $154.644 .768,2$ \\
Agustus, 2017 & Rp 209.557.500 & 27 & 5.658 .052 .500 & 729 & $155.030 .369,6$ \\
September, 2017 & Rp 131.488.000 & 29 & 3.813 .152 .000 & 841 & 155.415 .971 \\
Oktober, 2017 & Rp 125.438.500 & 31 & 3.888 .593 .500 & 961 & $155.801 .572,4$ \\
November, 2017 & Rp 102.672.700 & 33 & 3.388 .199 .100 & 1089 & $156.187 .173,8$ \\
Desember, 2017 & Rp 169.305.250 & 35 & 5.925 .683 .750 & 1225 & $156.572 .775,2$ \\
\hline Jumlah & Rp 5.393.691.025 & - & 2.996 .123 .525 & 15.540 & 5.393 .691 .025 \\
\hline
\end{tabular}

Berdasarkan tabel perhitungan omzet penjualan sepatu dan sandal menurut garis trend di atas dapat diketahui bahwa trend omzet penjualan sepatu dan sandal tahun 2015-2017 mengalami kenaikan. Hal tersebut dapat dilihat dari kolom omzet penjualan menurut trend dari kolom pertama trend omzet penjualan pada bulan Januari, 2015 sebesar 143.076.726,2 dan pada bulan kedua trend omzet penjualan sebesar 143.462.327,6. Pada bulan-bulan berikutnya trend omzet penjualan semakin mengalami kenaikan. Berikut ini adalah grafik trend omzet penjualan sepatu dan sandal tahun 2015-2017:

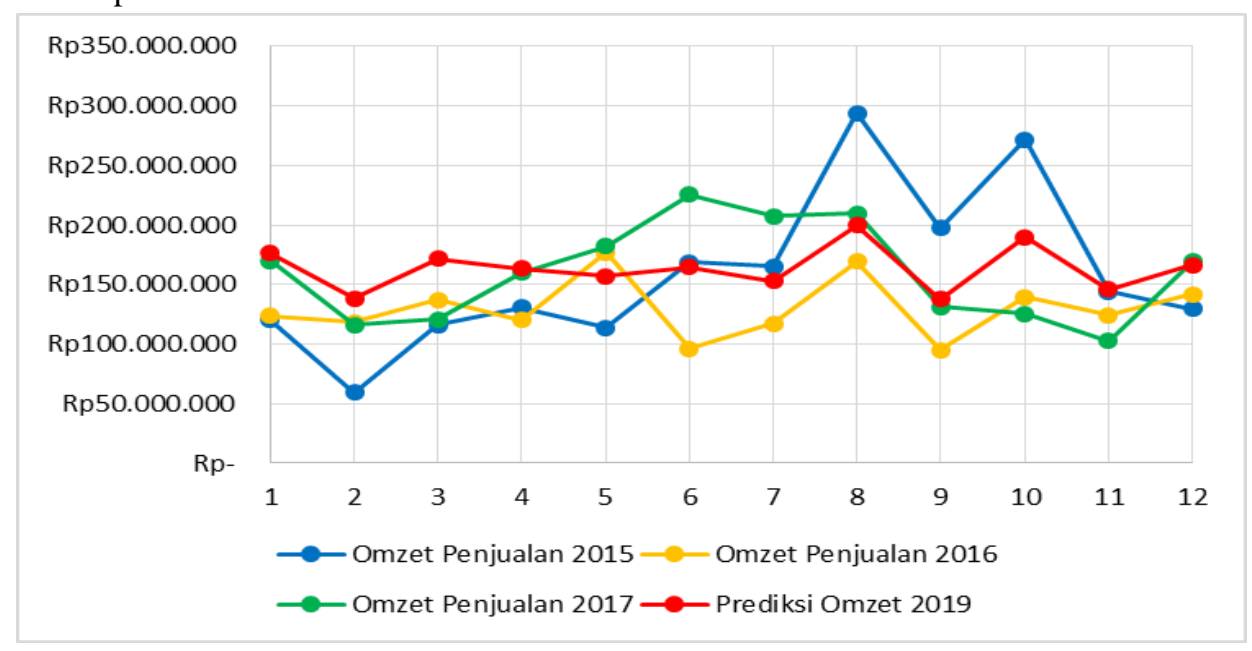

\section{Pembahasan}

Berdasarkan hasil penelitian yang dilakukan, diketahui bahwa trend omzet penjualan di CV. Pribadi Tiga selama 3 tahun menunjukkan garis peningkatan yaitu pada tahun 2015 sebesar 143.076.726,2 menjadi 156.572.775,2 pada tahun 2017. Trend omzet penjualan mengalami kenaikan pada tahun 2015 sampai tahun 2017. Pencapaian omzet penjualan di CV. Pribadi Tiga selama tahun 2015-2017 jumlah tertinggi terdapat pada tahun 2015 bulan ke-8 yaitu sebesar Rp 294.017.500 dan jumlah terendah juga pada tahun 2015 bulan ke-2 sebesar Rp 59.556.000. 
Pada tahun 2015 bulan Januari sampai bulan Juli omzet penjualan menunjukkan angka yang fluktuatif, pada bulan-bulan tersebut salah satu strategi pemasaran yang dilakukan oleh CV. Pribadi Tiga adalah mengadakan pelatihan menjahit sepatu dengan bahan selain kulit kepada masyarakat. Produk sepatu yang dihasilkan dari pelatihan tersebut dipasarkan di pasar sekitar Mojokerto dan juga dipasarkan di PPST (Pusat Perkulakan Sepatu Trowulan). Jumlah omzet penjualan tertinggi terdapat pada bulan Agustus yaitu sebesar Rp 294.017.500, dikarenakan terdapat 2 faktor yang menyebabkan omzet penjualan naik secara tajam. Yaitu (1) bertepatan dengan perayaan Hari Raya Idul Fitri, banyak konsumen melakukan pembelian sandal yang digunakan untuk hari raya; (2) dampak dari kebijakan pemerintah daerah yang melakukan pemesanan sepatu fantovel di CV. Pribadi Tiga untuk seluruh siswa baru di SMP Negeri Kota Mojokerto pada tahun ajaran baru. Pemesanan sepatu fantovel tersebut bertujuan untuk menyeragamkan atribut siswa baru di SMP Negeri Kota Mojokerto. Sebagai pengenalan terhadap produk industri rumahan di Kota Mojokerto, maka Walikota mewajibkan seluruh siswa terutama siswa baru menggunakan sepatu hasil produksi daerah sendiri. Hal tersebut memberikan pengaruh yang positif terhadap perkembangan perekonomian di Kota Mojokerto sendiri dan juga para pengrajin sepatu.

Tahun 2016 menunjukkan angka penurunan omzet penjualan dari tahun sebelumnya. Seperti yang disampaikan oleh pemilik CV. Pribadi Tiga sebagai berikut:

"Pada tahun 2016 omzet perusahaan sedikit menurun dari tahun 2015, karena persaingan semakin ketat terutama dengan produk China. Pada tahun ajaran baru pun permintaan sepatu untuk siswa baru di SMP Negeri Kota Mojokerto menjadi digilir, jadi hanya 2 sekolah saja yang memesan di CV. Pribadi Tiga." (AN, 53)".

Penurunan tersebut disebabkan oleh persaingan ketat dengan produk sepatu China yang membanjiri Jawa Timur dengan harga yang lebih murah dibandingan dengan CV. Pribadi Tiga. Persaingan bisnis merupakan perseteruan antara pelaku bisnis yang secara independen berusaha mendapatkan konsumen dengan menawarkan harga yang baik dengan kualitas barang atau jasa yang baik pula (Mujahidin, 2007:27). Selain persaingan dengan produk China, kebijakan pemerintah yang melakukan pesanan untuk 2 sekolah juga berpengaruh pada menurunnya pencapaian omzet penjualan pada tahun 2016. Jika dilihat selama satu tahun 2016 pencapaian omzet penjualan tertinggi terjadi pada bulan Mei yaitu sebesar Rp 176.895.000. Pencapaian omzet penjualan tertinggi pada bulan Mei tersebut disebabkan CV. Pribadi Tiga ikut serta dalam 2 event yaitu di Pesta Rakyat Kabupaten Mojokerto dan Gebyar Teknologi \& Pesta Rakyat Mojokerto dalam rangka memperingati HUT Kota Mojokerto.

Pada tahun 2017 pencapaian omzet penjualan mengalami peningkatan yang cukup tinggi, namun nilai trend cenderung menurun. Hal tersebut dikarenakan pada tahun 2017 CV. Pribadi Tiga berusaha untuk meningkatkan segala bentuk pelayanan yang diterapkan oleh perusahaan dan melakukan perbaikan guna meningkatkan omzet penjualan dari tahun sebelumnya, sehingga pada tahun 2017 didapatkan omzet penjualan yang meningkat. Pelayanan terbaru yang ditambahkan dalam kegiatan CV. Pribadi Tiga adalah melayani service sepatu, sandal maupun tas. Selama bulan Juni sampai Agustus CV. Pribadi Tiga mampu mempertahankan pencapaian omzet penjualan yaitu pada bulan Juni sebesar Rp 225.510.000, bulan Juli sebesar Rp 207.608.000, dan bulan Agustus sebesar Rp 209.557.500. Hal tersebut dikarenakan pada 3 bulan itu bertepatan dengan perayaan Hari Raya Idul Fitri dan perusahaan menerima pesanan dalam jumlah yang cukup besar untuk Sekolah Polisi dan juga Sekolah Keperawatan di Jawa Tengah. Selain itu juga CV. Pribadi Tiga mendapatkan pesanan dari PT. Angkasa Pura untuk membuat souvenir berupa gantungan tas yang akan dipergunakan untuk para wisatawan manca negara, dan juga pesanan dari Otoritas Jasa Keuangan (OJK) berupa dompet berbahan kulit sebagai tempat handphone dan perlengkapannya.

Trend omzet penjualan selama tiga tahun mengalami peningkatan yaitu pada bulan Januari tahun 2015 sebesar 143.076.726,2 menjadi 156.572.775,2 pada bulan Desember tahun 2017. Sehingga dapat disimpulkan bahwa berdasarkan perhitungan analisis trend, trend omzet penjualan di CV. Pribadi Tiga dari bulan Januari tahun 2015 sampai bulan Desember tahun 2017 mengalami peningkatan.

Perhitungan trend selama tiga tahun tersebut digunakan untuk menghitung prediksi (forecasting) tahun 2019. Berdasarkan persamaan trend yang ada prediksi omzet penjualan tahun 2019 juga mengalami kenaikan 
dan penurunan, namun hal tersebut tidak berpengaruh terhadap nilai trend prediksi omzet penjualan dikarenakan trend prediksi omzet penjualan tetap mengalami peningkatan pada tahun 2019.

\section{PENUTUP}

Berdasarkan hasil penelitian mengenai analisis trend omzet penjualan sepatu dan sandal di CV. Pribadi Tiga Kota Mojokerto tahun 2015-2017 dapat disimpulkan bahwa trend omzet penjualan sepatu dan sandal tahun 2015-2017 mengalami peningkatan dari tahun ke tahun meskipun jumlah pencapaian omzet penjualan fluktuatif. Hal ini digunakan untuk memprediksi pencapaian omzet penjualan dan trend omzet penjualan pada tahun 2019. Berdasarkan persamaan trend yang ada trend prediksi omzet penjualan tetap mengalami peningkatan pada tahun 2019.

Berdasarkan hasil penelitian ini, maka peneliti dapat memberikan saran yaitu CV. Pribadi Tiga lebih memaksimalkan penjualan produk-produk baik secara online maupun offline, serta terus meningkatkan berbagai pelayanan agar kualitas produk-produk menjadi lebih baik. Adanya peningkatan pelayanan tersebut diharapkan dapat meningkatkan penjualan yang lebih besar dan meningkatkan omzet penjualan yang lebih tinggi untuk tahun-tahun selanjutnya.

\section{DAFTAR PUSTAKA}

Atmaja, L. S. 2009. Statistika untuk Bisnis dan Ekonomi. Yogyakarta: Andi.

Hasan, I. 2009. Pokok-Pokok Materi Statistik 1 (Statistik Deskriptif). Jakarta: PT. Bumi Aksara

Kartajaya, H. 2010. Perjalanan Pemasaran Konsep Pemasaran. Jakarta: Erlangga

Mujahidin, A. 2007. Ekonomi Islam. Jakarta: PT. Raja Grafindo Persada

www.pajak.go.id 